\title{
Anticoccidial and antioxidant activities of zinc oxide nanoparticles on Eimeria papillata-induced infection in the jejunum
}

This article was published in the following Dove Press journal:

International Journal of Nanomedicine

I I March 2015

Number of times this article has been viewed

\section{Mohamed A Dkhil ${ }^{1,2}$ \\ Saleh AI-Quraishy' \\ Rizwan Wahab'}

'Department of Zoology, College of Science, King Saud University, Riyadh, Saudi Arabia; ${ }^{2}$ Department of Zoology and Entomology, Faculty of Science, Helwan University, Cairo, Egypt
Correspondence: Mohamed A Dkhil Department of Zoology, College of Science, King Saud University, PO Box 2455, Riyadh-I I45I, Saudi Arabia Tel +966 I| 4675754 Fax +966 II 46785 I4 Email mohameddkhil@yahoo.com

\begin{abstract}
Nanomedicine has recently emerged as a better option for the treatment of various diseases. Here, we investigated the in vivo anticoccidial properties of zinc oxide nanoparticles (ZNPs). ZNPs were crystalline in nature, with a smooth and spherical surface and a diameter in the range of $\sim 10-15 \mathrm{~nm}$. The X-ray diffraction pattern was utilized to identify the crystalline property of the grown ZNPs, whereas field emission scanning electron microscopy was employed to check the size and morphology of the ZNPs. The data showed that mice infected with Eimeria papillata produced $29.7 \times 10^{3} \pm 1,500$ oocysts/g feces on day 5 postinfection. This output was significantly decreased, to $12.5 \times 10^{3} \pm 1,000$ oocysts, in mice treated with ZNPs. Infection also induced inflammation and injury of the jejunum. This was evidenced (1) through an increase in the inflammatory histological score, (2) through increased production of nitric oxide and malondialdehyde, and (3) through a decrease in both the glutathione level and goblet cell number in mice jejuna. All these infection-induced parameters were significantly altered during treatment with ZNPs. Our results indicate, therefore, that ZNPs have protective effects against $E$. papillata-induced coccidiosis.
\end{abstract}

Keywords: zinc nanoparticle, Eimeria, mice, jejunum

\section{Introduction}

Research into nanotechnological approaches to infectious diseases is increasing rapidly, ${ }^{1}$ driven by the expectation that nanoparticles will be able to be used in the treatment of various diseases in the future. ${ }^{2}$

Zinc oxide nanoparticles (ZNPs) represent one such nanotechnological approach, and are characterized by their high catalytic efficiency and high adsorbing ability. ${ }^{3}$ Moreover, zinc is considered to be an essential trace element for various cellular activities ${ }^{4}$ and is a part of more than 200 enzymes. ${ }^{5}$ Recently, Ahmadi et $\mathrm{al}^{6}$ reported that dietary ZNPs improved oxidant state and had positive effect on the activity of several serum enzymes. ZNPs have also been reported to have antimicrobial activities. ${ }^{7}$ In addition, Nadhman et $\mathrm{al}^{8}$ used ZNPs as novel photosensitizers for photodynamic therapy against Leishmania.

Coccidiosis is a widespread disease affecting many vertebrates worldwide. It is caused by the unicellular eukaryote Eimeria, which exhibits approximately 800 different species. ${ }^{9}$ The most dangerous of these is Eimeria tenella, which causes significant economic losses in poultry farms. The current study was designed to investigate both the anticoccidial activity and the antioxidant role of ZNPs, using the murine Eimeria papillata as a model parasite for coccidiosis. 


\section{Material and methods}

\section{Synthesis of spherically shaped ZNPs}

The synthesis of ZNPs was performed by using zinc acetate dihydrate $\left(\mathrm{Zn}\left(\mathrm{CH}_{3} \mathrm{COO}\right)_{2} \cdot 2 \mathrm{H}_{2} \mathrm{O}\right)$ and octadecylamine $\left(\mathrm{CH}_{3}\left(\mathrm{CH}_{2}\right)_{17} \mathrm{NH}_{2}\right)$ as the source materials. In a typical experiment, zinc acetate dihydrate $(0.1 \mathrm{M})$ was dissolved in $100 \mathrm{~mL}$ methanol with octadecylamine $(0.05 \mathrm{M})$ under constant stirring (30 minutes) until it had completely dissolved. The zinc acetate dihydrate and octadecylamine were purchased from Sigma-Aldrich Corp (St Louis, MO, USA) and used without further purification. The obtained $\mathrm{pH}$ of the solution reached up to $\sim 12.5$. After the complete dissolution, the mixture was transferred to a refluxing pot and was refluxed at $\sim 65^{\circ} \mathrm{C}$ for 6 hours. Initially, no precipitate was formed in the refluxing pot, but as the refluxing time increased, small molecules of white precipitate were set at the bottom of the refluxing pot. After cooling the refluxing pot to room temperature, the white precipitate was transferred to a glass beaker and washed with methanol, ethanol, and acetone several times to remove any ionic impurities. The sample was then dried in a glass Petri dish at room temperature and was examined for its morphological and chemical properties.

\section{Characterization of ZNPs}

The morphology of the obtained white powder sample was characterized by using field emission scanning electron microscopy (FESEM), while the crystalline properties were examined by X-ray diffraction (XRD) with $\mathrm{Cu}_{\mathrm{K} \alpha}$ radiation $(\lambda=1.54178 \AA)$, in the range of $20^{\circ}$ to $65^{\circ}$ at a scan speed of $6 \%$ min. For FESEM observation, the white powder was sprayed onto carbon tape and coated with osmium tetroxide for 5 seconds. The sample was analyzed at room temperature. For more clarification related to crystalline characterization, including morphology of the grown ZNPs, the sample was further analyzed with transmission electron microscopy (TEM) equipped with high resolution (HR-TEM). For TEM measurement, nanostructures of white ZNP powder was sonicated in ethanol for 10-15 minutes; then, a carboncoated copper grid (400 mesh) was dipped in the suspension solution of nanoparticles and dried at room temperature, and the crystallinity and structural morphology were analyzed at $200 \mathrm{kV}$.

\section{Animals}

Twenty-four male C57BL/6 mice, weighing 25-30 g and aged 9-11 weeks, were obtained from the animal facilities of King Saud University, Riyadh, Saudi Arabia. The mice were fed a standard diet and water ad libitum. The experiments were approved by state authorities and followed Saudi Arabian rules for animal protection.

\section{Infection of mice}

To prepare the sporulated oocysts for the infection of the experimental mice, fecal pellets passed by infected mice were suspended in $2.5 \%(\mathrm{wt} / \mathrm{vol})$ potassium dichromate and diluted in saturated sodium chloride for oocyst flotation. Oocysts were counted in a McMaster chamber and expressed as number of oocysts per gram of wet feces. ${ }^{10}$

Animals were divided into three groups, with eight mice per group. The first group was the noninfected, control group, which was gavaged with $100 \mu \mathrm{L}$ of distilled water. The second and the third groups were orally inoculated with 1,000 sporulated oocysts of E. papillata suspended in $100 \mu \mathrm{L}$ distilled water. The third group also received an oral dose of $10 \mathrm{mg} / \mathrm{Kg}$ ZNPs suspended in $100 \mu \mathrm{L}$ distilled water daily for 5 consecutive days. The dose was chosen according to Alkaladi et al ${ }^{11}$ Powdered ZNPs were suspended in Milli-Q ${ }^{\circledR}$ water and were sonicated for 15 minutes at $40 \mathrm{~W}$, using a sonicator (Pro Scientific, Oxford, CT, USA), to form an homogeneous suspension before the treatments.

\section{Histopathology of the jejunum}

Mice jejuna were freshly prepared and fixed in 10\% neutral buffered formalin for 24 hours at room temperature. Specimens were then routinely dehydrated with ethanol and then, embedded in paraffin. After this, $5 \mu \mathrm{m}$ sections of the paraffin were stained with hematoxylin and eosin according to the method described by Drury and Wallington. ${ }^{12}$ These tissue sections were then scored for inflammatory lesions (infiltrations by mononuclear cells, neutrophils, eosinophils, and plasmacytes), for fibrin exudation and lymphangiectasis, for tissue destruction (enterocyte loss, ballooning degeneration, edema, and mucosal atrophy), and for tissue repair (hyperplasia, angiogenesis, granulomas, and fibrosis), according to the criteria established by Dommels et al. ${ }^{13} \mathrm{~A}$ rating score between 0 (no change from normal tissue) and 3 (involved most areas and all the layers of the intestinal section, including mucosa, muscle, and omental fat) was given for each aspect of inflammatory lesion, tissue destruction, and tissue repair. The sum of the inflammatory lesions, tissue destruction, and tissue repair scores was used to represent the total histological injury score for each section. In addition, the sum of the inflammatory lesions was multiplied by 2 to give more weight to this value where the tissue changes were mainly characterized by inflammatory lesions. ${ }^{13}$ 


\section{Number of goblet cells}

Sections were stained with Alcian blue for the identification of goblet cells. For each animal, the number of goblet cells in the jejunum was counted on at least ten well-oriented crypt-villous units (VCUs). Results were expressed as the mean number of goblet cells per ten VCUs. ${ }^{14}$ The number of parasitic infections in ten VCUs (mainly found within the crypt) was counted.

\section{Biochemical analysis}

Mice jejuna from all the groups were weighed and immediately homogenized to give $50 \%(\mathrm{w} / \mathrm{v})$ homogenate, in an ice-cold medium containing $50 \mathrm{mM}$ tris(hydroxymethyl) aminomethane (Tris)- $\mathrm{HCl}$ and $300 \mathrm{mM}$ sucrose. ${ }^{15}$ The homogenate was centrifuged at $500 \times g$ for 10 minutes, at $4^{\circ} \mathrm{C}$. The supernatant $(10 \%)$ was used for the various biochemical determinations.

\section{Glutathione (GSH)}

GSH was determined chemically in the jejunum homogenate using Ellman's reagent (5,5' dithiobis (2-nitrobenzoic acid)). ${ }^{16}$ The method is based on the reduction of Ellman's reagent with GSH to produce a yellow compound. The chromogen is directly proportional to the GSH concentration, and its absorbance was measured at $405 \mathrm{~nm}$.

\section{Malondialdehyde (MDA)}

Lipid peroxidation in plasma and jejunum homogenate was determined according to the method of Ohkawa et al ${ }^{17}$ by using $1 \mathrm{~mL}$ of trichloroacetic acid $10 \%$ and $1 \mathrm{~mL}$ of thiobarbituric acid $0.67 \%$, followed by heating in a boiling water bath for 30 minutes. Thiobarbituric acid-reactive substances were determined by the absorbance at $535 \mathrm{~nm}$ and expressed as MDA equivalents formed.

\section{Nitric oxide}

The assay of nitric oxide in plasma and jejunum homogenate was done according to the method of Berkels et al. ${ }^{18}$ In an acid medium and in the presence of nitrite, the formed nitrous acid diazotizes sulfanilamide, which is coupled with $N$-(1-naphthyl) ethylenediamine. The resulting azo dye has a bright reddish-purple color, which was measured at $540 \mathrm{~nm}$.

\section{Statistical analysis}

One-way ANOVA was carried out, and statistical comparisons between the groups were performed with Duncan's test, using a statistical package program (SPSS version 17.0).
All $P$-values were two-tailed, and $P<0.05$ was considered as significant for all the statistical analyses in this study.

\section{Results}

Figure 1 shows ZNPs at a low magnification (Figure 1A); the spherical structure in the image was formed by the assortment of several tiny NPs. The image also shows that the particles aggregated, with several particles being joined together in a clump formation. The image further indicates that the estimated diameter of each individual spherical nanoparticle was very small $(\sim 15-20 \mathrm{~nm})$, and that they had a smooth and clear morphology (Figure 1B). To further clarify the structural morphology of the grown nanoparticles, the nanostructures were reanalyzed at a higher magnification. This confirmed that the diameter of each NP was in the range of $\sim 15-20 \mathrm{~nm}$ (Figure 1C).

The size and shapes of the grown nanoparticles observed using FESEM analysis (Figure 1A-C) conformed closely to the XRD pattern (Figure 1D). The crystalline property of the grown material was analyzed with XRD. The obtained diffraction peaks, such as $<1010,<0002,<1011,<1012$, $<1120$, and $<1013$ were well-matched with the lattice constants of zinc oxide $\mathrm{a}=3.249$ and $\mathrm{c}=5.206 \AA$ (Figure 1D). The data matches well with the standard data issued by the Joint Committee on Powder Diffraction Standards (JCPDS 36-1451). In the XRD spectrum, no other peak was observed except for zinc oxide. The particle size of the ZNPs was calculated with the well-known Scherer formula, ${ }^{19}$ with full width at half maximum (FWHM) of XRD pattern, and the value of the peak position was as tabulated (Table S1), according to the formula:

$$
\mathrm{D}=\frac{0.9 \lambda}{\beta \cos \theta},
$$

where $\lambda$ is the wavelength of the $\mathrm{X}$-ray radiation source; $\beta$ is FWHM, in radians; and $\theta$ is Bragg's diffraction angle. The calculation was measured with the help of a Gaussian Lorentzian fitting program (Table S1). The average value of particle sizes was $\sim 13 \mathrm{~nm}$. The size of the grown ZNPs observed from FESEM analysis was consistent with the XRD (Figure 1D) pattern.

The structural morphology and crystallinity of the grown ZNPs was further confirmed via HR-TEM. Figure 1E show the TEM image at low magnification, whereas Figure $1 \mathrm{~F}$ illustrates the HR-TEM image of ZNP powder. From the image, it is clear that several spherically shaped ZNPs could be seen at low magnification (Figure 1E). The size of each nanoparticle was in the range of $10-15 \mathrm{~nm}$ and had a smooth 
A

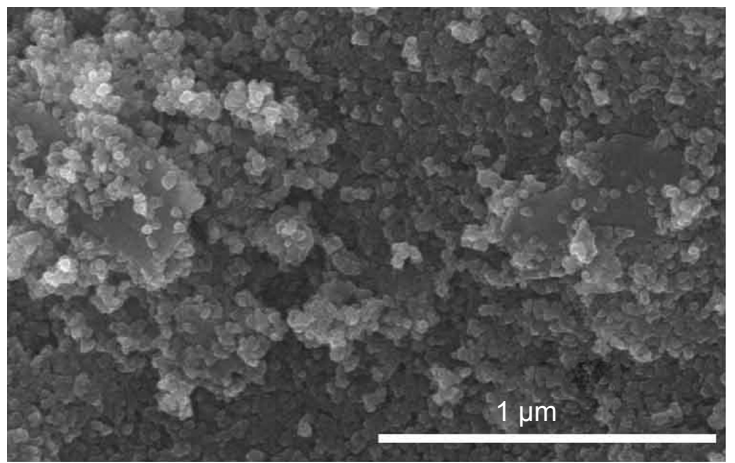

C

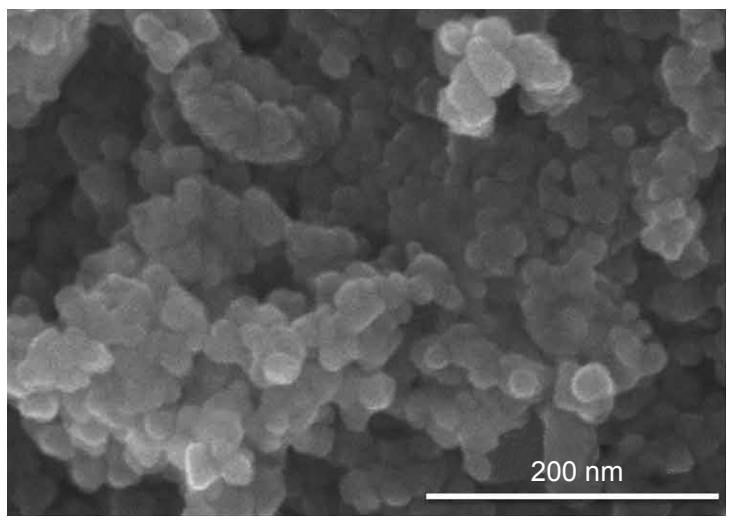

E

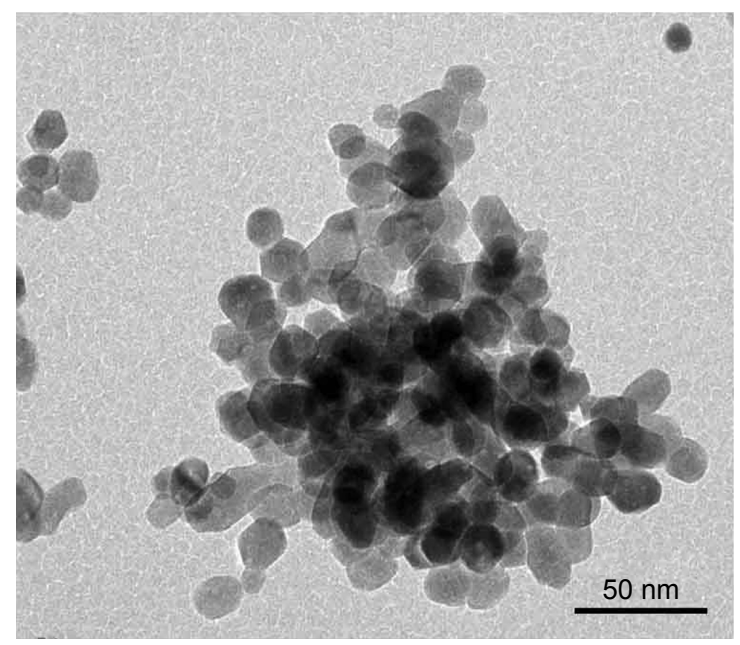

B

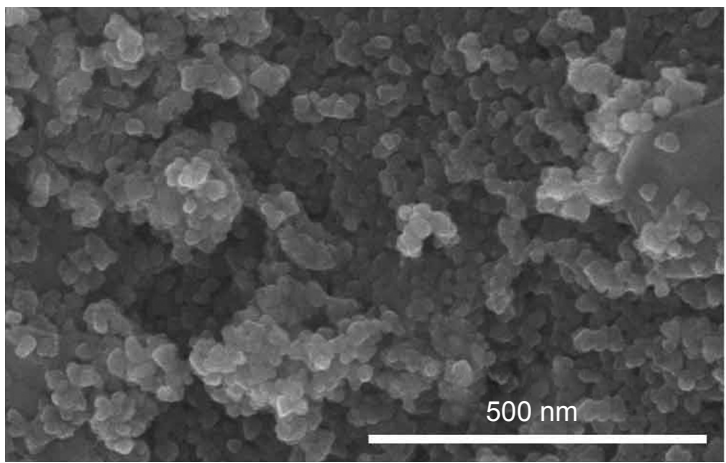

D

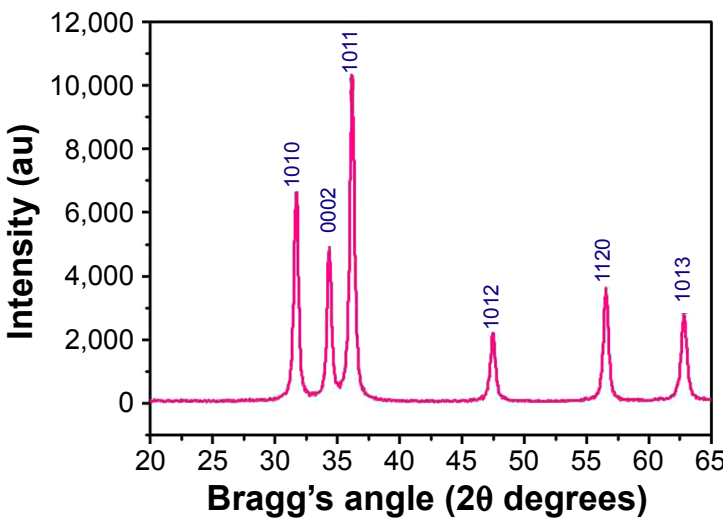

$\mathbf{F}$

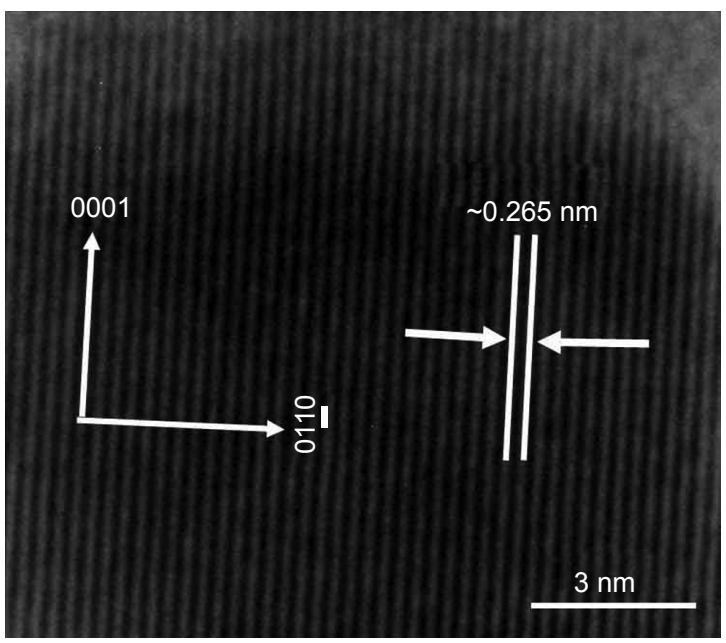

Figure I TEM images and X-ray diffraction pattern of ZNPs. (A-C), TEM images of ZNPs with different magnifications. (D) X-ray diffraction pattern of ZNPs. (E) The lowmagnification TEM image of ZNPs and their corresponding HR-TEM image, which presents (F) the lattice variance between two fringes, about $\sim 0.265 \mathrm{~nm}$.

Abbreviations: HR-TEM, high-resolution transmission electron microscopy; TEM, transmission electron microscopy; ZNP, zinc oxide nanoparticle.

surface, spherical shape, which is clearly consisted with the observed data of the FESEM images. The crystalline character of the grown nanostructures was observed with HR-TEM (Figure 1B and C) and showed the lattice fringe variance between two adjacent planes was about $0.265 \mathrm{~nm}$, which is closely analogous to commercial wurtzite zinc oxide. ${ }^{20-22}$ It is evident from the low-magnification TEM and HR-TEM images (Figure 1E and F) that the grown ZNPs were monocrystalline in nature.
Infection of mice with E. papillata sporulated oocysts led to the shedding of nonsporulated oocysts in the mice feces. On day 5 postinnoculation, the oocyst output was approximately $30 \times 10^{3}$ oocysts/g feces (Figure 1 ). The presence of ZNPs, meanwhile, was associated with a significant decrease in the oocyst output, by about $50 \%$ (Figure 2).

Through examination of the hematoxylin-eosin sections, it was clear that E. papillata induced remarkable histopathological changes in the infected jejunum. In addition, many 


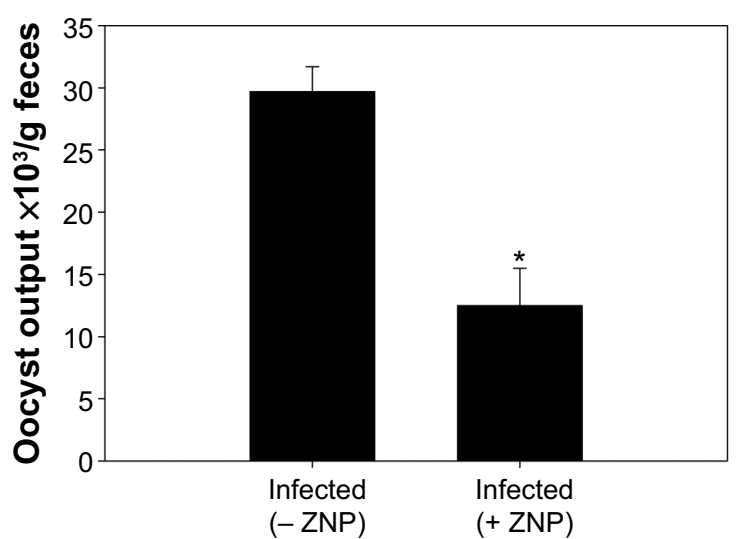

Figure 2 Oocyst output of mice 5 days after having been infected with 1,000 sporulated Eimeria papillata oocysts.

Notes: All values are expressed as mean $\pm S D$. *Significant change between infected ZNPs treated and untreated groups $(P \leq 0.05), \mathrm{n}=8$.

Abbreviations: SD, standard deviation; ZNP, zinc oxide nanoparticle.

developmental stages of the parasite were prominent in the jejuna villi (Figure 3). Figure 4 shows that the infected mice appeared to have moderate inflammatory injury, which accords with the work of Dommels et al. ${ }^{13}$ This injury was diminished when mice were treated with ZNPs. Also, the
E. papillata-infected mice jejuna appeared to contain a smaller number of developmental stages when treated with ZNPs (Figures 3 and 4).

Alcian blue-stained sections showed goblet cells as bluestained (Figure S1). On day 5 PI with E. papillata, the number of goblet cells was significantly decreased when compared with the control noninfected mice (Figure 5). ZNPs, however, were associated with the restoration of the number of goblet cells (Figure 5).

Infection of mice with E. papillata caused a significant decrease in the level of jejuna GSH (Table 1). Treatment of mice with ZNPs, however, was able to increase the level of GSH significantly when compared with both the noninfected and infected mice (Table 1). Furthermore, the infection induced a significant increase in the level of both nitric oxide and MDA (Table 1), but treatment with ZNPs improved both these parameters (Table 1).

\section{Discussion}

Zinc supplementation has been successfully used as a therapeutic and preventive agent for many conditions. ${ }^{23}$
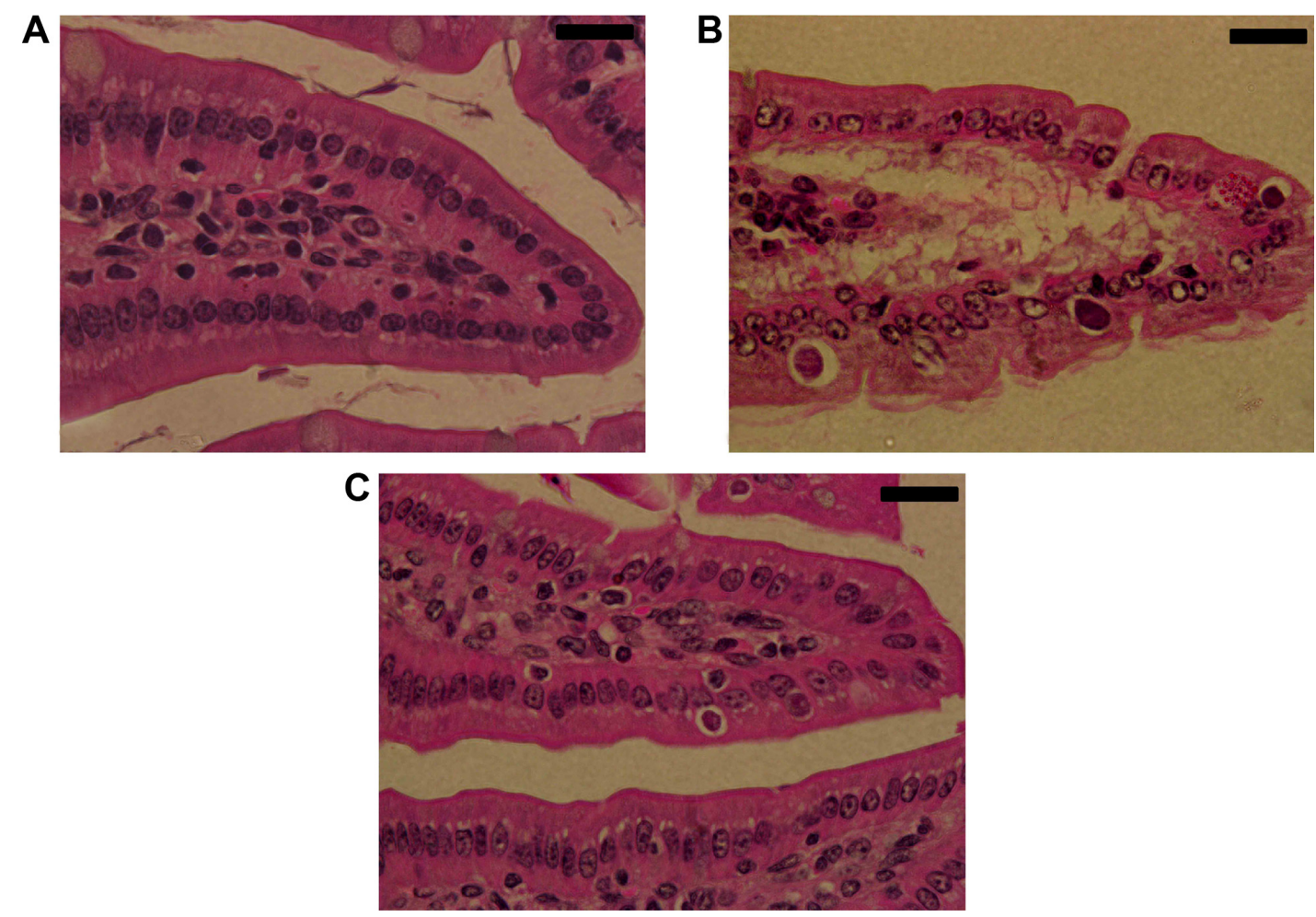

Figure 3 Effect of ZNPs on Eimeria papillata-induced jejunum injury on day 5. (A) Noninfected jejunum with normal architecture of the absorptive epithelium and lamina propria. (B) Infected jejunum with some pathological changes in lamina propria and absorptive epithelia. Developmental stages appearing in the absorptive epithelia. (C) Infected treated mouse exhibiting fewer parasites.

Notes: Sections are stained with hematoxylin and eosin. Bar $=25 \mu \mathrm{m}$.

Abbreviation: ZNP, zinc oxide nanoparticle. 


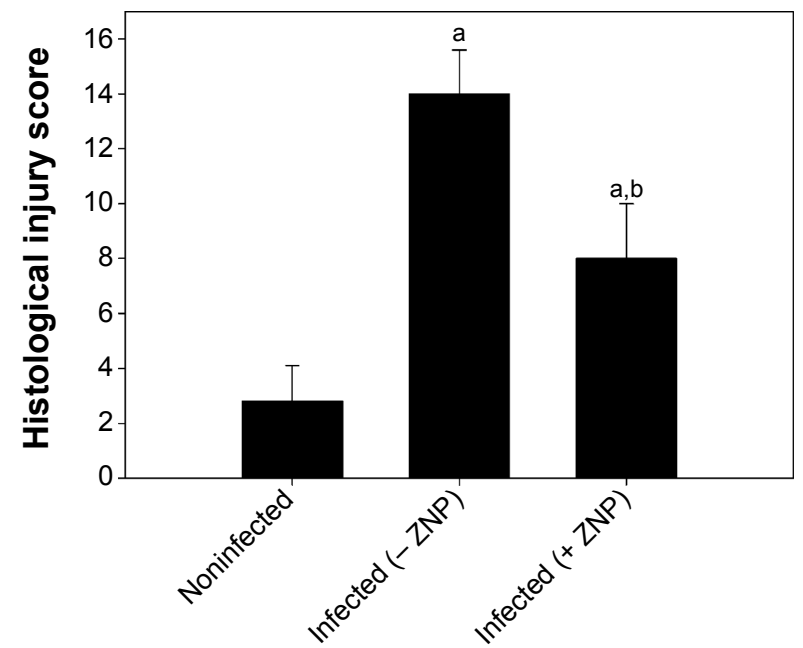

Figure 4 ZNP induced changes in the total histological injury score in jejunum of noninfected and Eimeria papillata-infected mice.

Notes: Scores were calculated according to Dommels et al. ${ }^{13}$ Values are expressed as mean \pm SD. aSignificant in respect to the noninfected $(-Z N P)$ group $(P \leq 0.05)$; bsignificant in respect to the infected $(-Z N P)$ group $(P \leq 0.05)$.

Abbreviations: SD, standard deviation; ZNP, zinc oxide nanoparticle.

Here, we have showed that ZNPs exhibit anticoccidial activity, evidenced as a significant lowering in the output of E. papillata oocysts within the feces of infected mice. This diminished output reflects that ZNPs impaired the development of parasites in the host before the relatively inert oocysts could be formed and finally released. The fact that ZNPs possess anticoccidial activity has not been reported before, but Bafundo et $\mathrm{al}^{24}$ demonstrated clearly that zinc utilization is diminished by Eimeria acervulina infection.

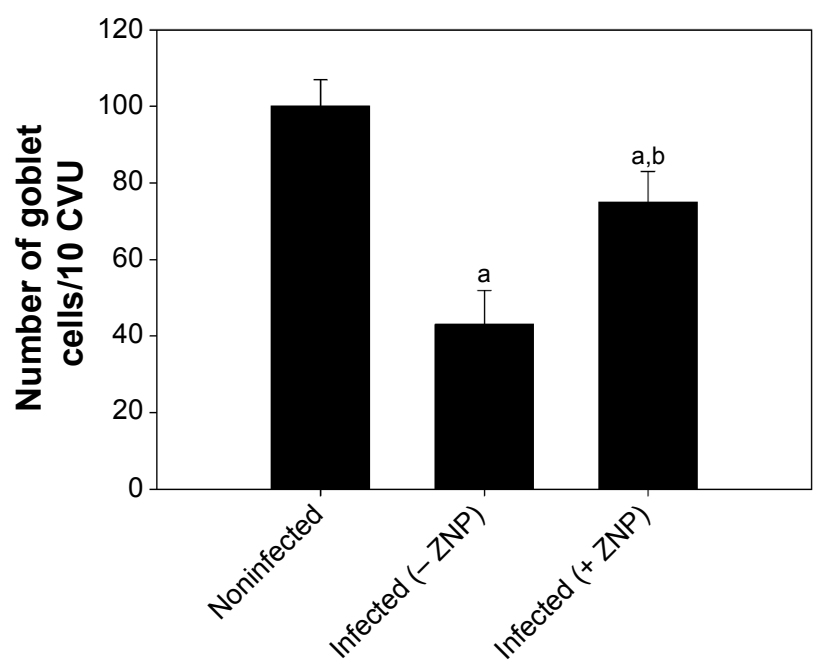

Figure 5 ZNP induced changes in the number of goblet cells in the jejunum of noninfected mice and mice infected with Eimeria papillata on day 5 postinnoculation. Notes: Data were obtained from Alcian blue-stained sections. Values are expressed as mean $\pm S D$. aSignificant in respect to the noninfected $(-Z N P)$ group $(P \leq 0.05)$; bsignificant in respect to the infected $(-Z N P)$ group $(P \leq 0.05)$.

Abbreviations: SD, standard deviation; CVU, crypt-villus unit; ZNP, zinc oxide nanoparticle.
Table I Zinc oxide nanoparticles ameliorates E. papillata induced changes in the level of jejunal glutathione, nitric oxide, and malondialdehyde

\begin{tabular}{llll}
\hline Group & $\begin{array}{l}\text { Glutathione } \\
(\mathbf{m g} / \mathbf{g})\end{array}$ & $\begin{array}{l}\text { Nitric oxide } \\
(\mu \mathrm{m} / \mathbf{g})\end{array}$ & $\begin{array}{l}\text { Malondialdehyde } \\
(\mathbf{n m} / \mathbf{g})\end{array}$ \\
\hline Noninfected (- ZNP) & $85 \pm 2.3$ & $65 \pm 2.2$ & $15 \pm 1$ \\
Infected (- ZNP) & $49.36 \pm 1.8^{\mathrm{a}}$ & $81.60 \pm 2.6^{\mathrm{a}}$ & $21.34 \pm 1.4^{\mathrm{a}}$ \\
Infected (+ ZNP) & $100.8 \pm 2.9^{\mathrm{a}, \mathrm{b}}$ & $41.14 \pm 2.4^{\mathrm{a}, \mathrm{b}}$ & $11.05 \pm 0.4^{\mathrm{a}, \mathrm{b}}$ \\
\hline
\end{tabular}

Notes: Values are expressed as mean $\pm S D$. a $P \leq 0.05$, significant against non-infected (- ZNP) group; ${ }^{b P} \leq 0.05$, significant against infected (- ZNP) group.

Abbreviations: ZNP, zinc oxide nanoparticle; SD, standard deviation.

The results of both biochemical and histological investigations further showed that while infection with E. papillata induced a marked injury of the jejunum through induction of oxidative stress, the administration of ZNPs helped to protect against these negative effects. It has previously been shown that E. papillata infections cause an inflammatory response in the jejunum of mice ${ }^{25}$ and that this response manifests itself as a perturbed jejunum structure and as a significant increase in nitric oxide and MDA levels. Zinc, meanwhile, has previously been used in the treatment of gastrointestinal inflammatory disorders, ${ }^{26}$ and ZNPs are known to be able to prevent the loss of GSH during oxidative damage induced by infection, as has been described by Dkhil et al. ${ }^{27}$ It is postulated that the active oxygen species generated by these metal oxide particles could be the main mechanism of their antibacterial activity. ${ }^{7}$ More generally, it is recognized that dietary trace elements/ antioxidants can help maintain an appropriate antioxidant balance in the case of many infections. ${ }^{28}$ Wunderlich et $\mathrm{al}^{4}$ for example, reported that zinc is fundamentally important for a balanced redox state, for the immune system, as well as for growth and development. More recently, Shoae-Hagh et al ${ }^{29}$ reported that ZNPs reduce apoptosis and oxidative stress values in isolated rat pancreatic islets.

Goblet cells are the major intestinal immunocompetent cells where they secrete mucous. ${ }^{30}$ The depletion of goblet cells was most evident in the infected jejuna villi, but there was no evidence of $E$. papillata infection within the goblet cells themselves. The decrease in the number of goblet cells induced by infection may be due to the damage caused by the parasite to the stem cells that produce goblet cells, which are present in the intestinal crypts. ${ }^{31}$ Yunus et $\mathrm{al}^{32}$ reported that changes in goblet cell numbers may affect the susceptibility of the parasite-infected host to limit the capacity of opportunistic pathogens from increasing or penetrating the local epithelium. Zinc supplementation significantly increased villus goblet cell numbers, ${ }^{33}$ and this increase in goblet cells seen in the group treated with ZNPs may be indicative of improved innate responses to E. papillata infection. 


\section{Conclusion}

In summary, we successfully prepared ZNPs, and the crystalline character, structure, phase, and morphology of the synthesized product were investigated. Our data also indicated that ZNPs exhibited anticoccidial and antioxidant properties, and it is proposed that they could be used as a feed additive, with minimal processing.

\section{Acknowledgment}

The authors would like to extend their sincere appreciation to the Deanship of Scientific Research at King Saud University for funding this research group (RG-1435-002).

\section{Disclosure}

The authors report no conflicts of interest in this work.

\section{References}

1. Allahverdiyev AM, Abamor ES, Bagirova M, et al. Antileishmanial effect of silver nanoparticles and their enhanced antiparasitic activity under ultraviolet light. Int J Nanomedicine. 2011;6:2705-2714.

2. Angeli E, Buzio R, Firpo G, et al. Nanotechnology applications in medicine. Tumori. 2008;94(2):206-215.

3. Bouwmeester H, Dekkers S, Noordam MY, et al. Review of health safety aspects of nanotechnologies in food production. Regul Toxicol Pharmacol. 2009;53(1):52-62.

4. Wunderlich F, Al-Quraishy S, Steinbrenner H, Sies H, Dkhil MA. Towards identifying novel anti-Eimeria agents: trace elements, vitamins, and plant-based natural products. Parasitol Res. 2014;113(10): 3547-3556.

5. Vallee BL, Falchuk KH. The biochemical basis of zinc physiology. Physiol Rev. 1993;73(1):79-118.

6. Ahmadi F, Ebrahimnezjad Y, Ghiasi ghalehkandi J, Maheri Sis N The effect of dietary zinc oxide nanoparticles on the antioxidant state and serum enzymes activity in broiler chickens during starter stage. Presented at: International Conference on Biological, Civil and Environmental Engineering (BCEE-2014); March 17-18; 2014; Dubai, UAE.

7. Sabir S, Arshad M, Chaudhari SK. Zinc oxide nanoparticles for revolutionizing agriculture: synthesis and applications. Scientific World Journal. 2014;2014:925494.

8. Nadhman A, Nazir S, Khan MI, et al. PEGylated silver doped zinc oxide nanoparticles as novel photosensitizers for photodynamic therapy against Leishmania. Free Radic Biol Med. 2014;77:230-238.

9. Mehlhorn H, editor. Encyclopedic Reference of Parasitology, Vol 1. 3rd ed. Berlin: Springer; 2008.

10. Schito ML, Barta JR, Chobotar B. Comparison of four murine Eimeria species in immunocompetent and immunodeficient mice. J Parasitol. 1996;82(2):255-262.

11. Alkaladi A, Abdelazim AM, Afifi M. Antidiabetic activity of zinc oxide and silver nanoparticles on streptozotocin-induced diabetic rats. Int J Mol Sci. 2014;15(2):2015-2023.

12. Drury RAB, Wallington EA. Carleton's Histological Technique. 5th ed. Oxford: Oxford University Press; 1980.
13. Dommels YE, Butts CA, Zhu S, et al. Characterization of intestinal inflammation and identification of related gene expression changes in mdr1a(-/-) mice. Genes Nutr. 2007;2(2):209-223.

14. Allen A, Hutton DA, Leonard AJ, Pearson JP, Sellers LA. The role of mucus in the protection of the gastroduodenal mucosa. Scand $J$ Gastroenterol Suppl. 1986;125:71-78.

15. Tsakiris S, Schulpis KH, Marinou K, Behrakis P. Protective effect of L-cysteine and glutathione on the modulated suckling rat brain $\mathrm{Na}+$, $\mathrm{K}+$, -ATPase and $\mathrm{Mg} 2+-\mathrm{ATPase}$ activities induced by the in vitro galactosaemia. Pharmacol Res. 2004;49(5):475-479.

16. Ellman GL. Tissue sulfhydryl groups. Arch Biochem Biophys. 1959; 82(1):70-77

17. Ohkawa $\mathrm{H}$, Ohishi N, Yagi K. Assay for lipid peroxides in animal tissues by thiobarbituric acid reaction. Anal Biochem. 1979;95(2):351-358.

18. Berkels R, Purol-Schnabel S, Roesen R. Measurement of nitric oxide by reconversion of nitrate/nitrite to NO. Methods Mol Biol. 2004; 279:1-8.

19. Cullity BD. Elements of X-ray Diffraction. Reading, MA: AddisonWesley Publishing Company; 1978

20. Wahab R, Mishra A, Yun SI, Kim YS, Shin HS. Antibacterial activity of $\mathrm{ZnO}$ nanoparticles prepared via non-hydrolytic solution route. Appl Microbiol Biotechnol. 2010;87(5):1917-1925.

21. Wahab R, Tripathy SK, Shin HS, et al. Photocatalytic oxidation of acetaldehyde with ZnO-quantum dots. Chem Engg J. 2013;226:154-160.

22. Wahab R, Dwivedi S, Umar A, et al. $\mathrm{ZnO}$ nanoparticles induce oxidative stress in Cloudman S91 melanoma cancer cells. J Biomed Nanotechnol. 2013;9(3):441-449.

23. Prasad AS. Zinc: role in immunity, oxidative stress and chronic inflammation. Curr Opin Clin Nutr Metab Care. 2009;12(6):646-652.

24. Bafundo KW, Baker DH, Fitzgerald PR. The iron-zinc interrelationship in the chick as influenced by Eimeria acervulina infection. J Nutr. 1984;114(7):1306-1312.

25. Dkhil MA, Abdel-Baki AA, Wunderlich F, Sies H, Al-Quraishy S. Dietary selenium affects intestinal development of Eimeria papillata in mice. Parasitol Res. 2014;113(1):267-274.

26. Scrimgeour AG, Condlin ML. Zinc and micronutrient combinations to combat gastrointestinal inflammation. Curr Opin Clin Nutr Metab Care. 2009;12(6):653-660.

27. Dkhil MA, Abdel-Baki AS, Wunderlich F, Sies H, Al-Quraishy S. Anticoccidial and antiinflammatory activity of garlic in murine Eimeria papillata infections. Vet Parasitol. 2011;175(1-2):66-72.

28. Evans P, Halliwell B. Micronutrients: oxidant/antioxidant status. $B r J$ Nutr. 2001;85 Suppl:S67-S74.

29. Shoae-Hagh P, Rahimifard M, Navaei-Nigjeh M, et al. Zinc oxide nanoparticles reduce apoptosis and oxidative stress values in isolated rat pancreatic islets. Biol Trace Elem Res. 2014;162(1-3):262-269.

30. Linh BK, Hayashi T, Horii Y. Eimeria vermiformis infection reduces goblet cells by multiplication in the crypt cells of the small intestine of C57BL/6 mice. Parasitol Res. 2009;104(4):789-794.

31. Cheng H. Origin, differentiation and renewal of the four main epithelial cell types in the mouse small intestine. II. Mucous cells. Am J Anat. 1974;141(4):481-501.

32. Yunus M, Horii Y, Makimura S, Smith AL. Murine goblet cell hypoplasia during Eimeria pragensis infection is ameliorated by clindamycin treatment. J Vet Med Sci. 2005;67(3):311-315.

33. de Queiroz CA, Fonseca SG, Frota PB, et al. Zinc treatment ameliorates diarrhea and intestinal inflammation in undernourished rats. $B M C$ Gastroenterol. 2014;14:136. 


\section{Supplementary materials}

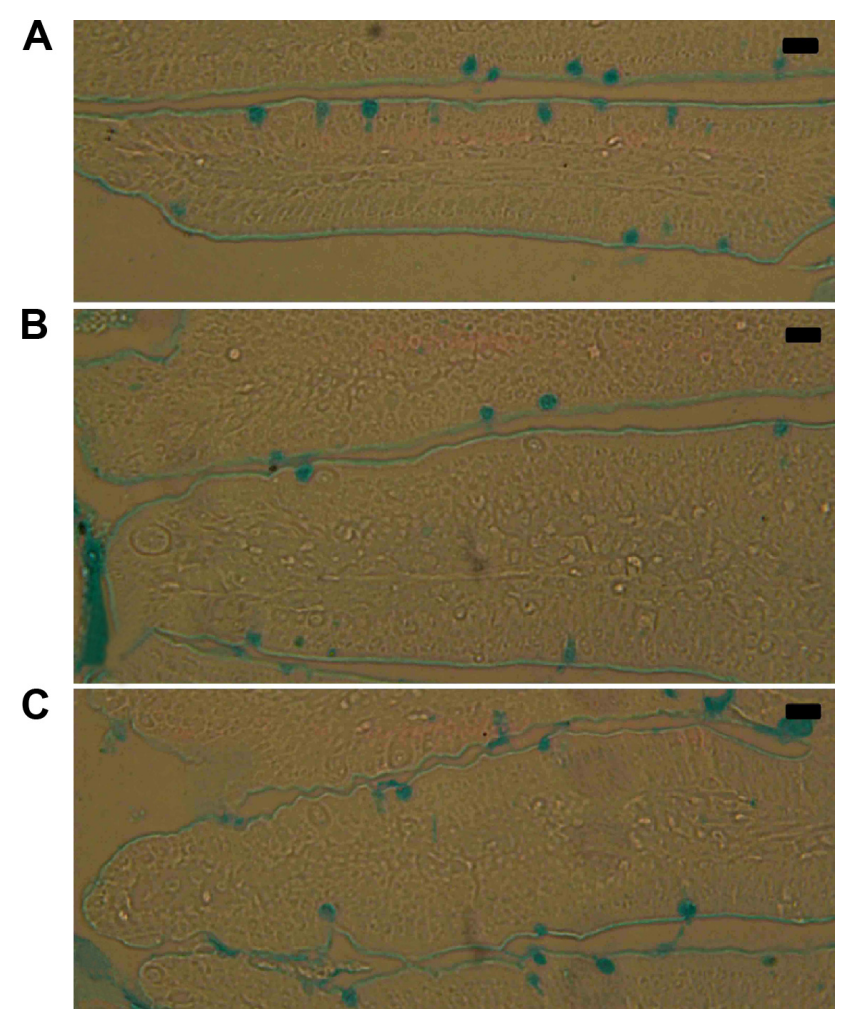

Figure SI Goblet cells in mouse jejuna. Section from noninfected control mice (A), from Eimeria papillata-infected mice (B), and from infected ZNP-treated mice (C). Notes: Sections were stained with Alcian blue. Bar $=50 \mu \mathrm{m}$.

Abbreviation: ZNP, zinc oxide nanoparticle.
Table SI Calculation of particle size of ZNPs from FWHM of X-ray diffraction pattern

\begin{tabular}{llllll}
\hline Phase & $\begin{array}{l}\text { Peak } \\
\text { position }\end{array}$ & $\begin{array}{l}\text { FWHM } \\
\text { (radians) }\end{array}$ & $\begin{array}{l}\text { Cos Bragg's } \\
\text { angle } \theta\end{array}$ & $\begin{array}{l}\text { Particle } \\
\text { size (nm) }\end{array}$ \\
\hline ZNPs & 1010 & $31.67^{\circ}$ & 0.010543 & 0.96205 & 13.668 \\
& 0002 & $34.33^{\circ}$ & 0.009201 & 0.95545 & 15.766 \\
& 1011 & $36.16^{\circ}$ & 0.010875 & 0.95062 & 13.406 \\
& 1012 & $47.46^{\circ}$ & 0.012688 & 0.91543 & 11.932 \\
1120 & $56.52^{\circ}$ & 0.014268 & 0.88080 & 11.028 \\
& 1013 & $62.80^{\circ}$ & 0.015158 & 0.85355 & 10.712 \\
\hline
\end{tabular}

Abbreviations: FWHM, full width at half maximum; ZNP, zinc oxide nanoparticle.
International Journal of Nanomedicine

\section{Publish your work in this journal}

The International Journal of Nanomedicine is an international, peerreviewed journal focusing on the application of nanotechnology in diagnostics, therapeutics, and drug delivery systems throughout the biomedical field. This journal is indexed on PubMed Central,

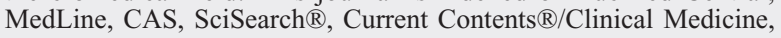

\section{Dovepress}

Journal Citation Reports/Science Edition, EMBase, Scopus and the Elsevier Bibliographic databases. The manuscript management system is completely online and includes a very quick and fair peer-review system, which is all easy to use. Visit http://www.dovepress.com/ testimonials.php to read real quotes from published authors. 